\title{
The Social Aspects of Transport
}

\author{
A. Daňková* \& I. Dostál \\ Transport Research Centre, Brno, Czech Republic \\ * Corresponding author: alena.dankova@cdv.cz
}

DOI: $10.2478 / \mathrm{v} 10158-011-0009-5$

\begin{abstract}
Spatial mobility is a very broad term in social sciences, and it can take various forms when we consider the mobility of people and things, the mobility of "pictures" or virtual mobility, much like the levels from the global to the international and even up to the micro-level of everyday life. From the mentioned range of topics, which definitely need not be considered exhaustive, it is apparent that transport should not be considered only a technical phenomenon and mobility only a geographical phenomenon. Both terms have a connection with a lot of social phenomena, they are influenced and they influence a range of social processes and structures, as far as the social stratification, change of social relations, social exclusion, or changes in urban spatial patterns is concerned. Transport systems should be developed and operated in such way that they would also support viable economic and a moral society, in which all individuals are alowed to develop their potential and enjoy the everyday quality of life. Additionally, these goals have to be met without the unfavorable influence on the artificial and natural environment in which the society exists.
\end{abstract}

KEY WORDS: Mobility, transport behavior, demand for transport.

\section{INTRODUCTION}

Every field of human activity, transport included, brings with it certain social aspects. From an objective point of view, transport itself as a whole is value-neutral and is of a purely purposeful nature. However, at every specific manifestation of transport it is possible to identify both positive and negative social features. In this respect, transport could help to form a bridge between various cultures or social groups, but on the other hand, it is one of the instances which creates barriers to mutual communication and beneficial co-existence.

In terms of transport, the guarantee of equal access for all groups of the population and an extension of lifestyle focused on consumption, which depends on the use of cars, are the most important social aspects. Additionally, attention is paid to the social view of demand for transport and its prediction as well. 


\section{EQUAL ACCESS TO TRANSPORT}

Movement and mobility have become the fundamental features of modern society; and their influence on a lot of aspects of life of the society has a growing tendency in connection with the globalization processes. However, not every citizen in the society has equal access to the same possibilities of transport as others. Although the freedom of movement is embedded in the "Charter of Fundamental Rights and Basic Freedoms" and the principle of equal access also follows other important European documents, mainly the European Social Charter, there are considerable discrepancies in the access to transport in society, which causes some social groups to be handicapped. It is up to the government to help overcome these barriers to equal access, because sustainable transport the transport which not only does not damage the environment, but also the transport which serves to all and does not handicap anyone.

\subsection{The handicapped groups}

In spite of the widely conceived definition of equal access to transport, it is apparent that it has a particular importance mainly for the so-called handicapped groups. Not only does it deal with the underprivileged, but also with the people who are physically or mentally handicapped, children, seniors, pregnant women, and parents with children or travellers with large luggage as well. It is estimated that all these groups together form almost half of the entire population and they are the majority users of public transport. It is necessary to classify women, who are often omitted in the planning and designing of transport projects, among these specific groups, taking into consideration the differentiation of their needs, Therefore, the public transport services, means of transport, and traffic space should be designed so as to allow the sufficient comfort for people from these handicapped groups as well. Meeting these demands is one of the most important criteria for the evaluation of equal access to transport.

There are, therefore, targeted and organized efforts to deal with the needs of the handicapped groups in the Czech Republic at the national, regional and local levels. One example is the "National Development Programme Mobility for All", within which the methodological handbook for the elimination of barriers within the transport systems was published (Šindelářová, 2002). There is a wide range of smaller regional and urban programs and projects which also try to contribute to guarantee equal access to transport (example.g. "Through Brno without barriers", "Barrier-free Olomouc", "Uničov a city without barriers").

\subsection{Transport integration of remote areas}

Currently, a huge problem in rural areas, and one of the main causes for their depopulation, is the insufficient transport service for smaller towns, villages, or settlements and hamlets in remote regions, which are considerably distant from metropolitan zones. In terms of the Czech Republic, the compact and dense structure of settlements virtually in the whole area of the country, and the great tradition in transport serviceability in rural areas by public transport, is a huge advantage. Nevertheless, after 1990, in connection with a gradual, and sometimes very fierce, restriction in the services of regional public transport, this problem started to occur in some regions of the Czech Republic as well. People in a lot of small villages without their own car are practically completely cut-off from the world, including the insufficient availability of medical and social services and offices. The poor level of transport service, together with a general lack of work opportunities in rural areas, then caused an increase in the urbanization processes, when mainly the young generation 
moves to larger urban areas for work, and typically older people stay in rural areas, which complicates the issue of the ageing population even more.

\subsection{Ageing of population}

The ageing of the population is another of a range of important issues which our society will have to deal with in a short time. The mobility of the elderly is characterized by many specifications which have to be taken into consideration. Older people are much more often dependent on public transport, which is, however, in many places replaced by individual transport at the expense of public transport. The stress and risks, which come with the ever increasing traffic volume on roads, mainly in urban areas, place increased demands on older drivers, who do errors more often. Therefore, transport has to be adapted to the trend of an ageing of the population, which will intensify even more in the following years, since population ages not only in the Czech Republic, but also throughout the whole world. Therefore, an initiative at the level of the UN was established, on whose basis the Czech Republic produced the "National Programme of Preparation for Ageing for the period of 2003 - 2007", approved by the Government of the Czech Republic in 2002.

It states two points related to transport:

1. "Within the transport policy, it is necessary to apply the specific demands laid on transport systems, considering the needs of the elderly and people with disabilities, mainly in terms of safety, availability, and stability. It is necessary to make the transport network accessible to all people, in terms of their mobility and without safety risks".

2. "On the basis of an all-society agreement, it is necessary to follow and meet the conditions for the transportation of the elderly via transport systems and conditions for the elderly in the field of telecommunication".

Considering the transport preferences of the elderly, it is necessary to focus on the creation of a barrier-free environment in public transport, and besides offering low- floor services also provide easy access to stops and railway stations, and to limit the construction of complicated overpasses and underpasses which the elderly and immobile people find rather difficult handle.

\subsection{Social exclusion}

Everyday mobility is a part of common social practice, which contributes to the creation of a social structure. By following normal social practice, in this case through using mobility services, people show their membership in the society and participate in reproducing the social order. There are many reasons why a lot of people cannot attain their social commitments due to their inability to maintain their everyday mobility. The problems with transport could form a significant barrier for the integration of individuals or whole groups into the society. The fact that people do not have access to various services is a consequence of social exclusion. For example, they are not able to use transport due to their low income, or the routes of the public transport do not lead to the right places. Age and disability are other common reasons which participate in the restriction of mobility.

The problems with providing of transport and the location of services may intensify the exclusion. They prevent people from accessing key local services and activities, e.g. to work, school, healthcare, the purchase of food, or free time activities. The problems may vary according to locality (rural - urban areas) or among various groups of people, 
and this burning issue concerns mostly the poor, the disabled, elderly, and families with children. So it comes down to the socio-economic spatial exclusion of some groups as an effect of the relations between social duties and the commitments of people, their individual resources (mainly time and financial opportunities), and the available transport infrastructure. This triangle of relations shapes the long-term patterns of transport behaviour of households, in which the choice of the means of transport or the planning of routes is not a matter of short-term calculation, but concerns long-term commitments and duties as well. The place of residence itself and the possibility of use of certain types of transport determine travel behaviour, e.g. the choice of certain schools, shops, or the choice of occupation.

\section{LIFESTYLE AND MOBILITY}

The degree and method of realized mobility is a reflection of the lifestyle of each individual up to a certain extent. Whereas this lifestyle is not unified for the whole population, it differs in various social groups. The technological progress, particulalry symbolized by the car, allowed the extension of the consuming lifestyle for middle and lower classes proportionally to the growth of availability of car ownership, tough tourism based on travelling by car, freight transport and related negative impacts of transport.

The lifestyle of higher classes has always been characterized by relatively high mobility. This can be traced back in history, where mainly higher classes of the society were those who travelled much more than others. This trend is still apparent, in spite of the mass growth of motoring; e.g. in the degree of the use of air transport, as one of the typical features of globalization. Thanks to transport, the limitations given by space and distance are disappearing, as they are easily surmountable, either virtually or in real life. Therefore, we can say that higher social classes live a global lifestyle. In contrast, lower social classes are characterized by low mobility and local lifestyle (Bauman, 1999). Whereas, the "globalists" have the freedom to travel almost anywhere and anytime, the "localists" are tied to the place of their life involuntarily, because they simply do not have enough resources to be able to afford costly travel. The local lifestyle predominates mainly in poor regions and developing countries.

The current society and the lifestyle which dominates is characterized by the strong position of the automobile culture, whose extreme form manifests as the dependence on cars. This phenomenon, known mainly from the USA, is characterized by a total permeation of the human environment, people's thoughts and lives, by cars, so that they could not imagine everyday life without them. This is aided not only by the efficient advertising of the automotive industry, but also by the adapting of the infrastructure in cities for cars at the expense of other types of transport; in doing so, the dependence on cars is becoming a forced and difficult-to-change fact. The dependence on cars has been an accompanying phenomenon of suburban processes, characteristic for surroundings of big cities, since the Second World War, first of all in the USA, and gradually in the countries of Western Europe, and then after 1989 in the Czech Republic as well (Havlíček \& Dostál, 2010). A new type of settlement occurs with suburbanization, and is characterized by the concentration of high income groups of the population in newly-built "ghettos", as only these groups could afford the new housing. Their lifestyle, strongly dependent on commuting by car to work, school, services, and culture, new localities are developed which are accessible only by car as it is not economical to introduce alternative types of transport there. The intensive use of cars leads to the creation of regular all-day and allweek congestions along access routes to these locations. The development of suburban colonies of family houses brings about hidden social segregation, as, in contrast to densely 
inhabited districts, they strain local and government budgets more for the maintenance of road infrastructure, lighting, power distribution, waste water systems, gas, because in low density population areas the expenses for these services are considerably higher.

A similar trend could be also found in the case of the commercial suburbanization, when newly developed huge commercial centres, appearing in suburban zones on green meadows in the vicinity of main road are only constructed in such a way that would be easily accessible by car. This is in contrast with other modes of transport which are largely neglected by investors of these centres.

Various alternative subcultures within the movement for the rights of pedestrians and cyclists try to fight against the increasing influence of motoring. This activity is often a part of an environmentally oriented non-governmental non-profit organization. A typical feature tends to be actions whose goal is to draw attention to certain problems and attract such a number of people which would allow to start to change the system. A known example from Czech cities is, for example, bike rides, which draw attention to the insufficient space dedicated to bicycle transport.

\section{DEMAND FOR TRANSPORT AND ITS PREDICTION}

The amount, time variation and spatial pattern of the demand for transport depend on a lot of characteristics, such as demographic, economic and social aspects, or the land-use. The following text is mainly focused on the problems of transport in urban agglomerations, which form the varied pattern of diversified economic and social relations and groups. Nevertheless, most of the facts could also be referred to on a regional or mesoregional level.

\subsection{Transport behaviour of inhabitants}

Various groups of inhabitants are also characterized by different transport behaviour which is influenced by their lifestyle, not only in terms of the absolute number of trips, but also in terms of the choice of destinations, or also the mode of transport used. The knowledge of the basic transport needs of various groups is a necessary prerequisite for the process of prediction of demand for transport.

There is a variety of different types of trips in everyday life of inhabitants in the city in relation to specific types of human activities and to the spatial location of these activities. Each type of land-use is characterised by origins and destinations for certain types of trips dependent on the factors of regularity, financial costs, types of housing, density and technological level of the given area (Ramadier et al., 2005). The trips which are forced are mostly given by regular activities, such as everyday commuting to work, while voluntary trips, whose realization depends only on the decision of the person who undergoes this journey. These two categories can be clearly differentiated and examples of such trips are noted in Table 1.

Another view of the evaluation of trips in cities is to find the purpose for which they are executed. The most common types are trips:

- shuttle- they usually contain routine journeys between the place of residence and the place of occupation, they have a high degree of regularity and repetition, and, therefore, they are well predictable, both in time and space; 
- work- trips executed for jobs mainly containing activities such as meetings or business meetings, which take place largely during working hours and, in terms of space, most often tend to be bound to places of occupation;

- personal- these are mostly arranged as voluntary trips and tend to be related to commercial activities, shopping and recreation;

- tourist- these mainly occur at places of historical or recreational importance, with accommodation facilities and restaurants; they are often of seasonal nature, or are linked to periods of special events, such as sports matches, congresses, or various festivals;

- logistic- a distribution of goods to satisfy the demand of both the consumers and producers; in terms of space, they are linked to areas of warehouses, distribution centres and retail areas.

Table 1: Classification of various types of trips in cities, depending on time and space.

\begin{tabular}{|c|c|c|c|c|}
\hline \multirow{2}{*}{\multicolumn{2}{|c|}{$\begin{array}{c}\text { Level of } \\
\text { spontaneity } \\
\text { of journey }\end{array}$}} & \multicolumn{3}{|c|}{ In space } \\
\hline & & regular & Irregular, planned & immediate \\
\hline \multirow{3}{*}{$\begin{array}{l}\text { In } \\
\text { time }\end{array}$} & regular & $\begin{array}{c}\text { routine } \\
\text { “I am at my workplace } \\
\text { daily from } 8 \text { am to } \\
4: 30 \mathrm{pm} "\end{array}$ & $\begin{array}{c}\text { fixed time, } \\
\text { agreed place } \\
\text { "We have our Friday's } \\
\text { beer today in the new } \\
\text { restaurant U Kořinků" }\end{array}$ & $\begin{array}{c}\text { fixed time } \\
\text { flexible place } \\
\text { "It is } 10 \text { o'clock - time for } \\
\text { my everyday morning coffee. } \\
\text { I've to stop at the nearest } \\
\text { coffee house" }\end{array}$ \\
\hline & $\begin{array}{l}\text { irregular } \\
\text { planned }\end{array}$ & $\begin{array}{c}\text { agreed time, } \\
\text { fixed place } \\
\text { “We'll meet tonight in } \\
\text { our favourite squash } \\
\text { club at } 6: 30 \text { pm” }\end{array}$ & $\begin{array}{c}\text { planned in advance } \\
\text { "We are going to see } \\
\text { that new movie at the } \\
\text { cinema Svět on Tuesday } \\
\text { at } 7 \text { pm." }\end{array}$ & $\begin{array}{c}\text { agreed time, } \\
\text { flexible place } \\
\text { "Today after six I shall call } \\
\text { my mother-in-law. I need to } \\
\text { find a phone box" }\end{array}$ \\
\hline & $\begin{array}{c}\text { immedia } \\
\text { te }\end{array}$ & $\begin{array}{l}\text { flexible time, } \\
\text { fixed place } \\
\text { "Sometime this week I } \\
\text { will have to stop at my } \\
\text { mother's and mow the } \\
\text { lawn in her garden" }\end{array}$ & $\begin{array}{c}\text { flexible time, } \\
\text { agreed place } \\
\text { "As I'm driving past the } \\
\text { office in Husova street, } \\
\text { I'll call by and pick up } \\
\text { working papers" }\end{array}$ & $\begin{array}{c}\text { impulsive } \\
\text { "Sale of clothes with } 50 \% \\
\text { off. I must go there there } \\
\text { immediately!" }\end{array}$ \\
\hline
\end{tabular}

A common inhabitant of a city makes 3-4 various trips daily on average, however, this figure may vary considerably according to individuals (Rodrigue et al., 2006). The number of trips. which start or end at a given locality and are made by a specific means of transport is some of the crucial information for transport planning. 


\subsection{The choice of a means of transport}

The choice of a transport mode by which each individual trip will be executed depends on a lot of factors, particularly on financial costs, out of which public transport costs considerably predominate over individual transport. However, there is also the viewpoint of the aspect of time and freedom of movement, which makes public transport increasingly uninteresting for certain groups of passengers (Dostál \& Dufek, 2007).

Therefore, the majority of users of public transport to not have a sufficient freedom of choice of the means of transport, particularly if they do not own a car. So millions of people cannot participate in the automobile transport; nevertheless, they share its social and environmental negative impacts. As an example, we can mention the vicinity of busy roads, where low-income groups of population live, as the rents are cheaper due to the noise and pollution. People with higher income prefer to move to more peaceful suburbs, from where they commute to centres by car and in doing so, they increase traffic volume, whose consequences are predominantly faced by others.

In this association the division of people between the so-called "choice riders" and "captive riders" is appropriate. The first group consists of people who have an opportunity to choose a beneficial and comfortable mean of transport for themselves - typically, economically active men travelling are rated in this group. The "captive riders" are those who do not have a choice in the selecting the means of transport, or are dependent on choices between less advantageous and less comfortable means of transport, which, according to the context, might be regarded public transport, bicycles, walking, etc. (Rutherford \& Wekerle, 1988). This group often consists of children, elderly people, the disabled, but women as well. This disadvantage in mobility is mainly produced by the unequal access to ownership of cars, which is a direct consequence of different income between various groups in the population.

\subsection{Modelling of demand for transport}

To forecast transport demand means to predict by different modelling techniques the changes, which will probably occur in traffic after a realization of an infrastructure construction or after a strategy measure will come into force. These changes have a direct impact on the quality of the environment, mainly the pollution and noise level. Both road traffic volumes as well as the number of passengers by public transport can be predicted. Road traffic volumes are affected by road engineering measures, such as the construction or reconstruction of roads, road closures, entry restrictions, speed redcution, etc.; whereas the number of people transported by public transport is changed through the influence of measures such as a new service in the urban public transport system, construction of a underground line, reconstruction of railway hubs, etc.

The entry data for modelling could be divided into three categories:

- socio-economic data: (number and socio-economical pattern of the population, number of jobs and schools, land-use),

- transport system data: (number of lanes, length of road section, average speed, etc.),

- special mathematic functions, which are used for traffic intensity in the network. 
The outcomes of modelling are:

- corresponding traffic volumes (number of passing vehicles or passengers on all sections of the network),

- travel time for all trips (this reflects delays at junctions and in congestions),

- emission flow of a given pollutant.

These results are calculated for each section of the modelled transport network and it is common that the model area of a larger city or region consists of even several thousand of sections. Therefore, modelling cannot be performed without a specialized computing software. Some examples of good quality software which is used worldwide are EMME/3, PTV (VISUM, VISEM), TRIPS, TRANSCAD, PARAMICS.

Modelling is performed through a set of several dozens of different scenarios. The basic scenario always reflects the current state, from which the modelling of other scenarios evolves, representing different versions of the area development, versions of the realization of construction projects, or the application of individual measures.

The first step in the creation of a basic scenario is to divide a model area into traffic zones, which are homogeneous from the viewpoint of trips origin and destination. If the modelled area is a city, each zone can represent, for example, a housing estate, the centre, a shopping centre, or an industrial site; while when modelling a larger region, the individual cities and villages represent the zones. The second step is the creation of a transport network graph of nodes and links, which usually represents a partially general transport network of the real area. Then follows the modelling itself, which consists of two basic parts:

1. Modelling of the transport demand gives answers to the questions: where from, where to, by which means of transport, and how many people are transported over a given period of time (e.g. hour, day, morning peak hour, etc.) and the resulting numbers of transported people are mathematically expressed in the form of the so-called "matrix of the transported relations",

2. Assignment, where the answer for the question "which way" is searched for, i.e. by which route, and, or by which services of public transport, are people transported.

The evaluation of the environmental impacts could be followed by the calculation of emissions with the help of transport volumes assigned in road network and the emission factors of various types of vehicles.

The prediction of transport demand in the future is prepared with the help of a perspective scenario, which differs from the basic scenario by taking into account the measures, which are considered for the implementation. The model transport network will be completed with planned roads and their parameters. The predictions for the development of the monitored socio-economic and demographic characteristics or changes in land-use in the individual zones are considered as well. If we model the measures of a financial nature, which could be, e.g. charging for use of the infrastructure or parking, it is necessary to complete the calculation of the functions with a parameter of costs. For example: in the scenario for evaluating the Park and Ride system, the approach of "intermediate zones" is used where extra zones representing localities considered for construction of parking facilities with good possibility of change to urban public transport are defined. This system helps to choose the optimum number and localization of such car parks in cities. Furthermore, 
the loading of the perspective network by the current matrix follows, which allows the perspective trafic volumes to be calculated on all sections of the modelled network.

The efficiency of individual measures tends to be evaluated as a difference between an appropriate future scenario with the current state. It could be the difference, both in absolute number of vehicles, as, e.g. the calculated reduction of emissions and the average time travelled by different means of transport.

\section{SUMMARY}

Spatial mobility is a very broad term in social sciences, and it can take various forms when we consider the mobility of people and things, the mobility of "images" or virtual mobility, as well as levels from the global and the international and up to the micro-level of everyday life. From the mentioned range of topics, which definitely need not be considered exhaustive, it is apparent that transport should not be considered only as a technical phenomenon and mobility only as a geographical phenomenon. Both terms are related to a lot of social phenomena, they are influenced and they influence a range of social processes and structures, be it the social stratification, change of social relations, social exclusion, or changes in urban spatial patterns. Transport systems should be developed and operated in such way that they would also support viable economics and a fair society, in which all individuals would be able to develop their potential and enjoy the everyday quality of life. Additionally, these goals have to be met without the unfavourable influence on the artificial and natural environment in which the society exists.

\section{ACKNOWLEDGEMENTS}

The research in this article was performed within the scope of a research project of the Ministry of Transport of the Czech Republic under contact No. MD 04499457501 "Sustainable Transport - Chance for the Future".

\section{REFERENCES}

Bauman, Z., 1999. Globalizace: Důsledky pro člověka [on-line]. Praha: Mladá fronta, 1999 [cit. 2006-10-10]. ISBN 978-0-08-044103-0. Dostupné také z: http://inpeg.ecn.cz/frames/globalizace/bauman.html (in Czech)

Dostál, I., Dufek, J., 2007. Modelling of travel time of public and individual transport in urban area. In 10th International Scientific Conference Mobilita '07, Bratislava (Slovakia), 24.-25.5.2007. Bratislava (Slovakia): Vydavatel'stvo STU, pp. 187-190. ISBN 978-80-227-2648-1.

Havlíček, M., Dostál, 2010. I. Projevy suburbanizace ve změnách využití krajiny v Jihomoravském kraji a zázemí města Brna. Acta Pruhoniciana, 2010 (94), pp. 65-76. ISSN 0374-5651. (in Czech) 
Ramadieer, T., Lee-Gosselin, M., Frenette, A., 2005. Conceptual Perspectives for Explaining Spatio-Temporal Behaviour in Urban Areas. In Lee-Gosselin, M., Doherty, S. (eds.) Integrated Land-Use and Transportation Models. Amsterdam: Elsevier, pp. 87-99. ISBN 0-08-044669-8.

Rodrigue, J.P., Comtois, C., Slack, B., 2006. The Geography of Transport Systems. New York: Routledge, 284 p. ISBN 0-415-35441-2.

Rutherford, B.M., Wekerle, G.R., 1988. Captive rider, captive labor: Spatial constraints and women's employment. Urban Geography, Issue 2, pp. 116-137. ISSN 0272-3638.

Šindelářová, T. et al., 2002. Návod pro naplňování rozvojového programu mobility pro všechny: 1. díl - Nová kvalita místních dopravních systémů. Praha: Mobilis, o.s., 2002, 133 p. (in Czech) 